\title{
An evaluation of immunomagnetic separation-real-time PCR (IMS-RTiPCR) combined assay for rapid and specific detection of Escherichia coli O157:H7 in raw milk and ground beef
}

\author{
Birce MERCANOGLU TABAN ${ }^{1 *}$ (D), Sait Aykut AYTAC ${ }^{2}$
}

\begin{abstract}
The aim of this study is to optimize a rapid and specific method for detection of E. coli O157:H7 (EHEC) from food samples with high background flora using an immunomagnetic separation-real-time polymerase chain reaction assay (IMS-RTiPCR). For this, EHEC cells were recovered from raw milk and ground meat samples that were artificially contaminated to the final concentrations of $10^{1}, 10^{3}$ and $10^{5} \mathrm{cfu}$ EHEC/mL or g, after a non-selective pre-enrichment at $35^{\circ} \mathrm{C}$ for $8 \mathrm{~h}$ following either with or without capturing by micro-sized beads. Then, EHEC cells were identified by RTiPCR. The study was also carried out without any enrichment to evaluate the enrichment efficiency of the assay. By comparing the assay with and without pre-enrichment, we showed that even the usage of specific micro-sized beads did not improve EHEC detection in raw milk and ground beef samples and so gave false negative results unless an 8-h pre-enrichment was applied. Besides, the assay can be completed in less than $9 \mathrm{~h}$ with a minimum detection limit of $10^{3} \mathrm{cfu} \mathrm{EHEC} / \mathrm{mL}$ or $\mathrm{g}$ in foods and hence was found to be simple routine-based method that exhibits great potential for implementing as a rapid screening of EHEC in microbial tests as compared to existing techniques.
\end{abstract}

Keywords: Escherichia coli 0157:H7; immunomagnetic separation; milk; raw ground beef; real-time PCR.

Practical Application: IMS-RTiPCR assay's detection time is $<9 \mathrm{~h}$ (including an 8 -h pre-enrichment) in raw milk and ground beef.

\section{Introduction}

Escherichia coli O157:H7 (EHEC) which is an enterohemorrhagic serotype of the Shiga toxin-producing E. coli (STEC), is considered a serious public health problem since it is recognized as a major pathogen of foodborne diseases in humans with a capable of causing diseases like diarrhea, hemorrhagic colitis $(\mathrm{HC})$, the potentially fatal hemolytic uremic syndrome (HUS), thrombotic thrombocytopenic purpura (TTP), and kidney failure (Qin et al., 2018; Jaakkonen et al., 2017). Despite the wide-scale distribution of EHEC in all types of foods, it is primarily transmitted through cattle and so raw or undercooked minced or ground beef (Centers for Disease Control and Prevention, 1997; King et al., 2014; Xiong et al., 2014), but milk and dairy products including especially raw or inadequately pasteurized milk (Kumar et al., 2013; Goh et al., 2002; Allerberger et al., 2001), yoghurt (Morgan et al., 1993), and raw-milk cheeses (Gaulin et al., 2012; Honish et al., 2005) have also been highly susceptible to contamination by EHEC. A multistate outbreak occurred in the US in 2014 (Kraft et al., 2017) and the outbreak in France in 2011 (King et al., 2014) were both linked to EHEC contamination in ground beefs. In 2010, 41 patients reported to be ill with EHEC due to consuming aged raw-milk Gouda cheese in the US (McCollum et al., 2012). There was an EHEC outbreak linked to raw milk cheese in Quebec, Canada in 2008 (Gaulin et al., 2012) and in late 2005, an outbreak of EHEC was also associated with raw milk consumption in the US (Denny et al., 2008). Another outbreak of EHEC was associated with unpasteurized-milk Gouda cheese in Canada in late 2002 (Honish et al., 2005). Based on all these outbreaks, detecting EHEC in foods before they reach to the consumer has become an important step in preventing EHEC-associated foodborne outbreaks. However since raw milk and ground beef have relatively short shelf lives than other types of foods, timely, specific, sensitive, and accurate detection of this pathogen is important to assess the safety of them and is of great importance for public health reasons (Kumar et al., 2013).

Conventional cultural methods (CCM) and classical polymerase chain reaction (PCR) assays are still the most common methods used in pathogen detection in foods. In despite of their good specificity and reliability, they have some disadvantages. CCM for detection and identification of EHEC are very laborious and time-consuming due to the required non-selective and selective enrichment steps to achieve a critical threshold concentration needed for the isolation of the target pathogen and subsequent biochemical and serological tests for the identification of the target pathogen, as well as classical PCR assays which require extra laborious steps for pre-concentrating a small amount of bacterial cells from a large volume of liquid sample and for providing DNA templates without PCR inhibitors, immunomagnetic separation (IMS) technique has been used in combination with them in order to capture and concentrate bacterial cells present at low concentration in food matrices with a high background flora 
to overcome these problems (Ganesh et al., 2016; Chen et al., 2014; Mercanoglu Taban \& Aytac, 2009).

IMS, which is based on the specific binding of the target pathogen to the hydrophobic and magnetized surface of the uniform micro-sized beads with adsorbed antibodies, has been used for separation and concentration of the target pathogen from foods containing competitive microflora and inhibitors by shortening the time of enrichment and removing impurities (Mercanoglu \& Aytac, 2006). Therefore, the integration of IMS method is used to improve the microbial analysis performance, providing concentration of the target pathogen, reducing the total analysis time required for the enrichment steps and the limits of detection, as well as eliminating the complex matrix effect of food samples and PCR inhibitors (Luo et al., 2017; Xiong et al., 2014).

Numerous rapid and specific detection methods for EHEC have been developed. Indeed, IMS is coupled with most of these techniques, primarily immunoassays (Wang et al., 2011), immunosensors (Mendonca et al., 2012), and nucleic acid-based assays (Wang et al., 2014; Zhao et al., 2010). However, there are still problems with their specificity and sensitivity. In addition, in most of these methods, there had been a need of optimization of several enrichment procedures to improve the recovery of target bacteria with IMS in complex food matrices (Weagant et al., 2011; Weagant \& Bound, 2001). Hence in this study, a rapid, specific, and sensitive combined assay was optimized and developed for EHEC, comprising sequential an 8-h non-selective enrichment, followed by IMS-RTiPCR. In addition, this study demonstrated the inability of IMS-RTiPCR combined assay in detection of EHEC in raw milk and ground beef samples unless any enrichment step was used. Therefore, this study highlights the need of a rapid assay for continually monitoring the presence of EHEC in a comprehensive range of complex food matrices.

\section{Materials and methods}

\subsection{Bacterial strains and culture conditions}

EHEC, obtained from Dr. Doyle, Georgia University was used as the reference strain in all through the study. Pure cultures of EHEC were grown in modified tryptic soy broth (mTSB, Merck, Germany) at $35^{\circ} \mathrm{C}$ for $18-24 \mathrm{~h}$. Tenfold serial dilution of the reference strain was made with $\mathrm{NaCl}(0.85 \%)$ (Sigma-Aldrich, the USA) as the diluent and aliquots were taken for EHEC enumeration ( $\mathrm{cfu} / \mathrm{mL}$ ) on CT-SMAC plates containing sorbitol MacConkey agar (Merck, Germany) supplemented with cefixime and potassium tellurite (Merck, Germany) and then incubated at $37{ }^{\circ} \mathrm{C}$ for $18-24 \mathrm{~h}$. The other pure cultures of Salmonella spp., Shigella spp., Yersinia enterocolitica, E. coli, Listeria monocytogenes, and Staphylococcus aureus used in the specificity testing of the combined method, was from the culture collection of the authors.

\subsection{Food sample preparation and non-selective enrichment}

In this study, raw milk and ground beef samples were obtained from local grocery stores and a level of artificially inoculation of $10^{1}, 10^{3}$ and $10^{5} \mathrm{cfu} \mathrm{EHEC} / \mathrm{mL}$ raw milk or $/ \mathrm{g}$ of ground beef was used for testing. Non-contaminated control samples were also prepared to determine if the background flora contained EHEC and if there were false positive results from the non-contaminated food samples. Hence; prior to the inoculation of EHEC, raw milk and ground beef samples were examined for natural contamination with EHEC by ISO 16654:2001 horizontal method (International Standard Organization, 2001) and confirmed as negative. This result was also confirmed by the result of combined assay.

Firstly, 25 grams of raw ground beef was mixed with $225 \mathrm{~mL}$ of buffered peptone water (BPW, Merck, Germany) and then was stomached (Seward 400 Stomacher, Norfolk, the UK) for $1 \mathrm{~min}$. On the other hand; $25 \mathrm{~mL}$ of raw milk was mixed with $225 \mathrm{~mL}$ of BPW in a sterile flask. Both food samples were then inoculated with decimally diluted cultures of EHEC to the final concentrations of $10^{3}$ and $10^{5} \mathrm{cfu} \mathrm{EHEC} / \mathrm{mL}$, and the target bacteria were subsequently captured by superparamagnetic micro-sized beads according to the IMS procedure given below, and also after a non-selective pre-enrichment at $35^{\circ} \mathrm{C}$ for $8 \mathrm{~h}$. Mercanoglu \& Aytac (2006) carried out another study without the usage of these micro-sized beads of which the specificity and the recovery sensitivity had been tested.

\subsection{IMS procedure}

Standard procedure according to the Dynal Manual (Dynal, 2000) was followed throughout the separation and concentration of target bacteria from both pre-enriched and non-enriched raw milk and ground beef samples. During IMS; target bacteria, from $1 \mathrm{~mL}$ of samples mixed with $20 \mu \mathrm{L}$ of bead suspension, are specifically caught onto magnetic beads coated with anti-E.coli O157 antibodies (Dynal, Norway). The bead-bacteria complexes were separated using a magnetic particle concentrator (Dynal, Norway) and washed three times with washing buffer $(0.15 \mathrm{M}$ $\mathrm{NaCl}, 0.01 \mathrm{M}$ Na-phosphate buffer, $0.05 \%$ Tween 20; pH 7.4) to remove food debris and other microorganisms (Mercanoglu \& Aytac, 2006). The beads were then resuspended in different volumes of phosphate-buffered saline according to the DNA extraction and purification method used.

\subsection{RTiPCR assay}

Foodproof ${ }^{\circledR}$ Sample Preparation Kit I (Roche/BIOTECON Diagnostics, Germany) procedure was used (Roche/BIOTECON Diagnostics, 2007) for rapid preparation of DNAs of target bacteria from bead-bacteria complex suspensions or directly from homogenized samples after an 8-h pre-enrichment and without any enrichment. Following the extraction of DNAs from these cultures, the isolated DNAs were analyzed by RTiPCR assay by using the foodproof ${ }^{\circledR}$ E. coli O157 detection kit (Roche/BIOTECON Diagnostics, Germany) according to its recommended PCR procedures (Roche/BIOTECON Diagnostics, 2017). The RTiPCR reaction mix contains $15 \mu \mathrm{L}$ of master mix including premixed primers and hybridization probes for sequence-specific detection and other reagents, $1 \mu \mathrm{L}$ of convenient enzyme solution, $5 \mu \mathrm{L}$ of sample DNA, and $1 \mu \mathrm{L}$ of internal amplification control (IAC) for reliable interpretation of results. After mixing all these reagents, $20 \mu \mathrm{L}$ of RTiPCR reaction mix was subjected to analysis using a real-time thermalcycler (LightCycler ${ }^{\circledR}$ carousel-based system-Roche/BIOTECON 
Diagnostics, Germany) which was used for amplification with reaction conditions including heat denaturation at $95{ }^{\circ} \mathrm{C}$ for $10 \mathrm{~min}$, and then 45 cycles at $95^{\circ} \mathrm{C}$ for $0 \mathrm{~s}$, annealing at $59^{\circ} \mathrm{C}$ for $30 \mathrm{~s}$, and extension at $72^{\circ} \mathrm{C}$ for $5 \mathrm{~s}$, followed by the cooling at $40{ }^{\circ} \mathrm{C}$ for $30 \mathrm{~s}$ (Roche/BIOTECON Diagnostics, 2017). This RTiPCR assay simultaneously amplifies and detects fragments of a gene that is located in the $\mathrm{O}$ antigen gene cluster of EHEC by using sequence-specific primers in a PCR. The IAC, which is a nontarget xenosequence oligonucleotide present in the same sample reaction tube, was coamplified simultaneously with the target sequence with corresponding primers and probes at the same amplification conditions used in the RTiPCR (Nordstrom et al., 2007). All the runs in this study were carried out in duplicates and in each test, DNA of pure reference strain and ultra-pure $\mathrm{H}_{2} \mathrm{O}$ served as positive and negative controls, respectively.

Real-time thermalcycler used in this study detects the amplicons through the fluorescence generated by their corresponding pair of sequence-specific hybridization probes, which are both fluorescently-labeled oligonucleotides, in real time. For each amplicon, a donor probe was labeled with a fluorescein at the 3 '-end, and an acceptor probe was labeled with a real-time thermalcyler specific red fluorophore (LightCycler ${ }^{\circledR}$ Red 640) at the 5'-end. During the annealing step of each PCR cycle, donor probe absorbs light from the blue light source of the real-time thermalcycler and an adjacent acceptor probe absorbs resonance energy from this donor probe, which results in fluorescence resonance energy transfer (FRET) between them. The real-time thermalcycler measures this emitted fluorescence of the thermalcyler specific red fluorophore (Roche/BIOTECON Diagnostics, 2017).

\subsection{Specificity and sensitivity study}

The specificity of IMS-RTiPCR combined assay was determined by using the EHEC reference strain and by pure cultures of other pathogenic bacteria such as Salmonella spp., Shigella spp., Yersinia enterocolitica, Escherichia coli, Listeria monocytogenes, and Staphylococcus aureus which can likely to be found within these foods together with EHEC. Moreover; raw milk and ground beef samples that were found as EHEC-negative by ISO 16654:2001 horizontal method (International Standard Organization, 2001), were also analyzed by combined method for control. For the sensitivity analysis of the combined assay which was repeated two times, tenfold serial dilution of the reference strain was made up to a final volume of $1 \mathrm{~mL}$ to obtain final bacterial concentrations ranging from $10^{8}$ to $10^{1} \mathrm{cfu} \mathrm{EHEC} / \mathrm{mL}$. All bacterial solutions were subjected firstly to IMS and then the DNAs of each bacteria from bead-bacteria complex suspensions were prepared using Foodproof ${ }^{\circledast}$ Sample Preparation Kit I as mentioned above, and $5 \mathrm{~mL}$ aliquots from each isolated DNA was subjected to RTiPCR amplification.

\section{Results and discussion}

\subsection{Specificity and sensitivity performance of IMS-RTiPCR assay}

The specificity of the combined assay is a function of both IMS method and RTiPCR assay. The absorbed antibodies of the micro-sized beads specifically targets the somatic antigen of EHEC and RTiPCR primers and probes target the fragments of a gene located in the $\mathrm{O}$ antigen gene cluster of EHEC. To confirm the specificity of IMS-RTiPCR combined assay for EHEC detection, other pathogenic strains, which are common foodborne bacteria, were subjected to the same IMS-RTiPCR combined assay. As seen in Figure 1, the results showed that the combined assay has high specificity for detection of EHEC cells since the pathogens other than the target bacteria did not give any positive, specific EHEC amplification signal even they were likely to be captured by the micro-sized beads. In addition; no amplification signal was observed in the study with non-contaminated raw milk and ground beef samples. This result correlates with and confirms the result of ISO 16654:2001 horizontal method (International Standard Organization, 2001). For the sensitivity of the combined assay, the lowest dilution of the reference strain that consistently

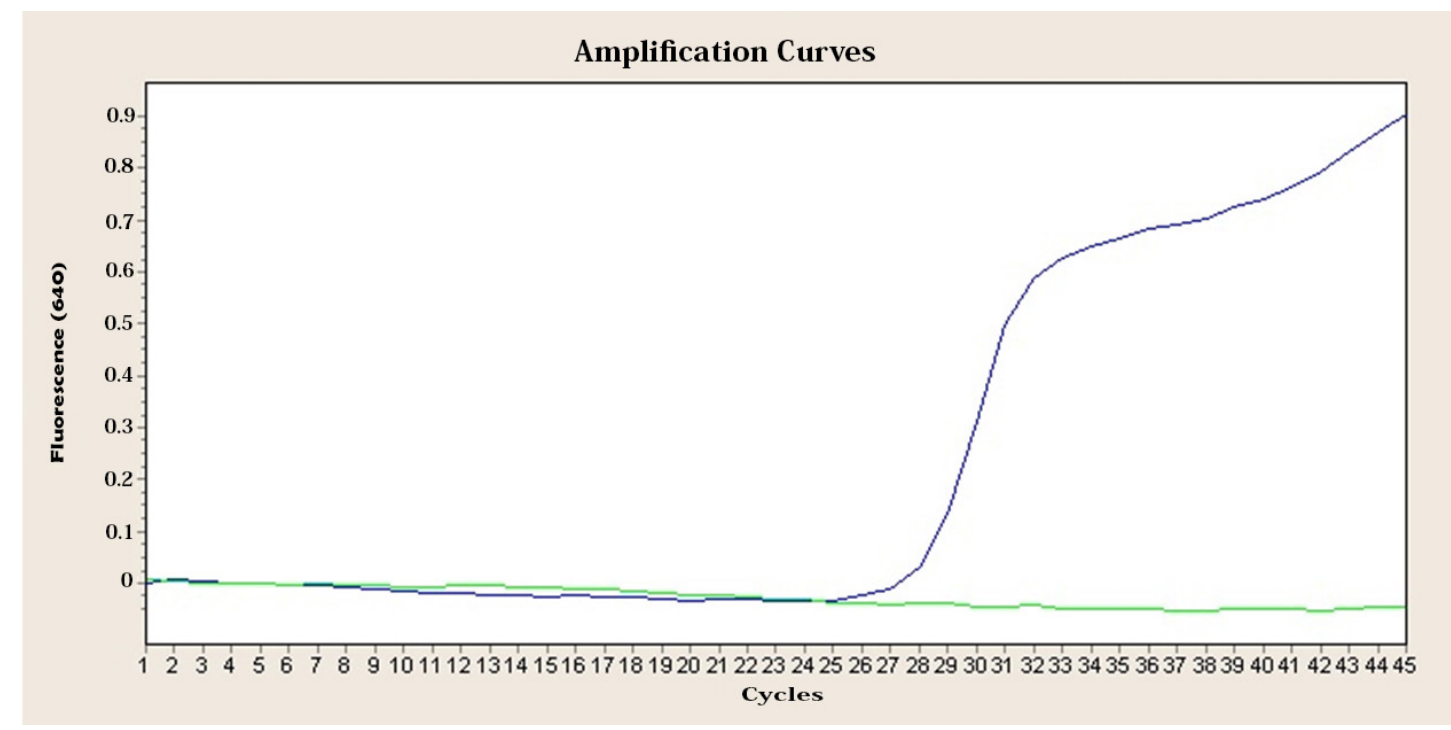

Figure 1. Specificity of the IMS-RTiPCR combined assay. Blue graphic: EHEC; Green graphic: Other pathogenic strains. 
produced an amplified signal was taken as the limit of detection. The minimum detection limit of EHEC in pure cultures was found as $10^{1} \mathrm{cfu} \mathrm{EHEC} / \mathrm{mL}$ (data not shown).

\subsection{Detection of EHEC in artificially contaminated raw milk and ground beef samples by IMS-RTiPCR assay (with and without a pre-enrichment)}

With artificially contaminated raw milk and ground beef samples, the combined assay did not detect any EHEC cell unless a pre-enrichment was applied. This may be due to both the complexity of food matrices and high levels of natural microflora or to the capture efficiency (CE) of the micro-sized beads. In other words; both food matrices potentially include high levels of natural microflora which undoubtedly interfered with isolation and detection, in addition to the high contents of many milk- and meat-associated inhibitors, fat particulates and proteins that might both entrap the low amounts of target pathogen and interfere with the antibody or the bacterial surface causing the blockage of formation of bead-bacteria complexes (Fedio et al., 2011; Fu et al., 2005). Besides, since the Brownian movement of specific antibodies immobilized on these micro-sized beads is weak, the efficiency of the immunologic reaction between these specific immobilized antibodies and epitopes on the surface of the target bacteria appears to be rather poor than the ones of free antibodies in a large separation volume. To overcome this weakness and to ensure high $\mathrm{CE}$ of the micro-sized beads to the target bacteria, a large amount of antibodies and beads could be used in a large-volume IMS (Fedio et al., 2011). However; the practical application of large-volume IMS is limited due to its very high cost (Luo et al., 2017). Previous studies also reported that both the binding capacity of the beads (Jeníková et al., 2000) and the final amplification signal of the real-time PCR assay (Fu et al., 2005) were decreased significantly when detection was performed with high fat content ground beef. Aydin et al. (2014) also concluded that the sensitivity of IMS coupled with tyramide signal amplification assay without using any enrichment step was decreased two- to fivefold compared to the results of the study done with pure cultures, to the detection limits of $2.5 \times 10^{2}$ and $10^{2} \mathrm{cfu}$ EHEC/mL-g in ground beef and milk samples respectively, due to the food matrix effect. Likewise in our study, the number of bacteria directly captured from food samples by IMS method could not support RTiPCR amplification even when the amount of target bacteria was $10^{1}-10^{5} \mathrm{cfu}$ $\mathrm{EHEC} / \mathrm{mL}$ or $\mathrm{g}$ in all food samples. Herewith, a pre-enrichment was applied as a very necessary step for EHEC detection before the combined assay in order to overcome these problems and to increase the sensitivity of detection since it also supports the growth rate and so the final cell concentration of freeze-injured EHEC cells in these foods (Lionberg et al., 2003). Similar to our study; Weagant et al. (2011) reported that $0.1-0.3 \mathrm{cfu}$ E. coli/g in artificially inoculated alfalfa sprouts gave an amplification signal when if IMS method used only after a 5-h enrichment time. According to the results of another study done with IMS followed by loop-mediated isothermal amplification (LAMP), the combined assay captured and detected a bacterial concentration as low as $3 \times 10^{1} \mathrm{cfu} / \mathrm{mL}$ from the meat samples within a 6 -h total analysis time when if a 4 -h short pre-enrichment was applied (Qin et al., 2018). On the contrary; Fu et al. (2005), who firstly combined IMS and RTiPCR for detection of EHEC, found the minimum detection limit of IMS-RTiPCR combined assay as $<5 \times 10^{2}$ cells $/ \mathrm{mL}$ for EHEC suspensions in buffer and as $1.3 \times 10^{4}$ cells/g in ground beef without using any enrichment step within an 8-h total analysis time. This was also an acceptable rapid assay, but the detection limit of EHEC is higher than our minimum detection limit.

IMS-RTiPCR combined assay has also been used to isolate and detect other foodborne pathogens from food matrices containing high fat and protein (Luo et al., 2017; Mercanoglu \& Griffiths, 2005; Yang et al., 2007). In most of these studies, again either a non-selective or a selective pre-enrichment step was still required to detect low levels of foodborne pathogens. Mercanoglu \& Griffiths (2005), showed that at least a 10-h non-selective pre-enrichment was needed in detecting 1.5 and 25 cfu Salmonella/25 g in alfalfa sprouts and ground beef samples, respectively, to achieve a detectable level by IMS-RTiPCR combined assay. On the other hand, Luo et al. (2017) found the detection limit of the IMS-RTiPCR combined assay as $8 \times 10 \mathrm{cfu}$ L. monocytogenes $/ \mathrm{mL}$ in pure culture and $8 \times 10^{1} \mathrm{cfu} / \mathrm{mL}$ in pasteurized milk without any pre-enrichment process in $<7$ hours. However, they preferred to use a 2-step magnetic separation method which seemed to provide a high immunoreaction efficiency compared with that of our IMS method.

RTiPCR assay has all the advantages of specificity and rapidity. However; in our study, the individual RTiPCR assay also could not detect any EHEC cell even after an 8-h pre-enrichment of the food samples. This might be due to the inorganic and organic PCR inhibitors found in complex raw milk and ground beef matrices such as calcium ions, lactoferrin, serum proteins, collagen, myoglobin, and haemoglobin (Schrader et al., 2012) since RTiPCR depends on both efficient DNA extraction and removal of PCR inhibitors (Yang et al., 2007). In a previous study, due to the PCR inhibitors found in raw pork samples, pathogens even at a concentration of $10^{7} \mathrm{cfu} / \mathrm{mL}$ could not be detected by PCR (Rodriguez-Lázaro et al., 2005). Dai et al. (2017) also concluded that PCR amplification gave false negative results unless IMS was used in chicken meat samples. These results indicated that IMS method improved the sensitivity of the combined assay by preventing DNA loss due to the milk- and meat-associated PCR inhibitors. In other words; the use of IMS method after pre-enrichment with RTiPCR assay indicates that the interference in binding capacity due to the inhibitors and high fat and protein contents of foods, is obviated. Indeed, at least a pre-enrichment time of $8 \mathrm{~h}$ in a non-selective medium was found to be sufficient in order to detect EHEC in both raw milk and ground beef samples by combined assay. Food safety applications and methods also require enrichment step prior to IMS method.

However; in our study, the combined assay did not show a great sensitivity as to detect $10^{1} \mathrm{cfu} \mathrm{EHEC} / \mathrm{mL}$ or $\mathrm{g}$ in either of the foods like it did in pure cultures. Nevertheless, it was found to have the same minimum detection limit of $10^{3} \mathrm{cfu} / \mathrm{mL}$ or $\mathrm{g}$ in both of the food types with an overall detection time $<9 \mathrm{~h}$. [including the steps of non-selective pre-enrichment $(8 \mathrm{~h})$, selective capture of the target pathogen using IMS (30 min), and amplification of the target pathogen-selective DNA sequences using RTiPCR (30 min)], where the negative control without EHEC cells did not increase in fluorescence above background levels (Figure 2). 


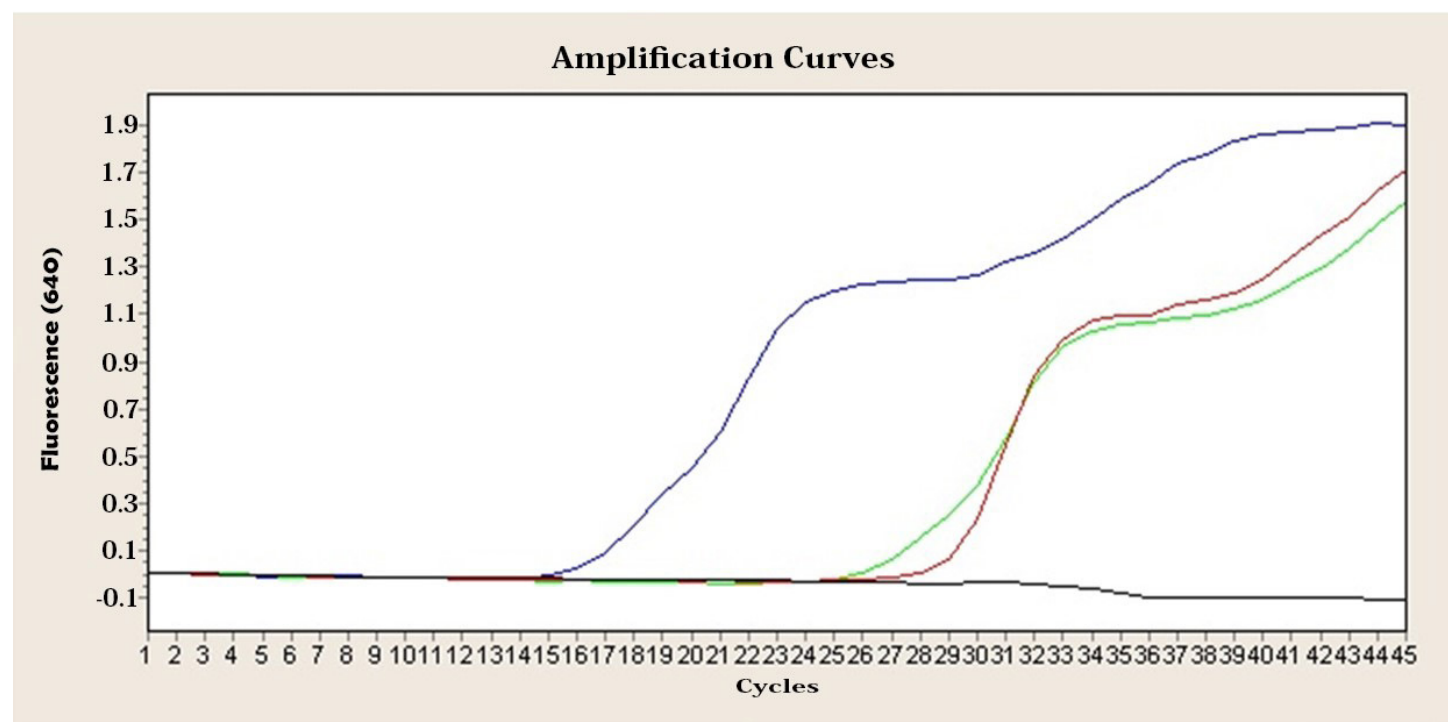

Figure 2. IMS-RTiPCR combined assay with artificially contaminated food samples. Blue graphic: EHEC; Black graphic: Negatif control; Green graphic: $10^{5} \mathrm{cfu}$ EHEC/mL; Red graphic: $10^{3} \mathrm{cfu}$ EHEC/mL.

\section{Conclusion}

Consequently, by comparing the combined method with and without a pre-enrichment, the experimental results demonstrated that even the usage of these specific micro-sized beads did not improve EHEC detection in raw milk and ground beef samples and so gave false negative results unless a pre-enrichment applied. So; the use of this combined assay by food industry and food microbial analysis laboratories that are responsible from food safety and quality assurance, will shorten the detection time long before the foods are laid for consumption. The most of all, this combined assay will aid in the development of control measures for EHEC in not only raw milk and ground beef but also in freshly consumed leafy green vegetables which carry the potential risk of microbiological contamination due to the usage of untreated irrigation water, inappropriate organic fertilizers, wildlife or other sources that can occur anywhere from the farm to the fork. Furthermore, researchers has started to develop novel methods with improvements in terms of distinction of the viable cells from dead ones by IMS-RTiPCR combined methods.

\section{References}

Allerberger, F., Wagner, M., Schweiger, P., Rammer, H.-P., Resch, A., Dierich, M. P., Friedrich, A. W., \& Karch, H. (2001). Escherichia coli O157 infections and unpasteurised milk. Eurosurveillance, 6(10), 147151. http://dx.doi.org/10.2807/esm.06.10.00379-en. PMid:11891383.

Aydın, M., Herzig, G. P., Jeong, K. C., Dunigan, S., Shah, P., \& Ahn, S. (2014). Rapid and sensitive detection of Escherichia coli O157:H7 in milk and ground beef using magnetic bead-based immunoassay coupled with tyramide signal amplification. Journal of Food Protection, 77(1), 100-105. http://dx.doi.org/10.4315/0362-028X.JFP-13-274. PMid:24406005.

Centers for Disease Control and Prevention - CDC. (1997). Escherichia coli O157:H7 infections associated with eating a nationally distributed commercial brand of frozen ground beef patties and burgers-Colorado. Morbidity and Mortality Weekly Report, 46(33), 777-778. PMid:9272586.
Chen, J., Shi, X., Gehring, A. G., \& Paoli, G. C. (2014). Automated immunomagnetic separation for the detection of Escherichia coli O157:H7 from spinach. International Journal of Food Microbiology, 179(2), 33-37. http://dx.doi.org/10.1016/j.ijfoodmicro.2014.03.022. PMid:24718031.

Dai, F., Zhang, M., Xu, D., Yang, Y., Wang, J., Li, M., \& Du, M. (2017). The development of methods for the detection of Salmonella in chickens by a combination of immunomagnetic separation and PCRs. Biotechnology and Applied Biochemistry, 64(6), 888-894. http://dx.doi.org/10.1002/bab.1539. PMid:27730684.

Denny, J., Bhat, M., \& Eckmann, K. (2008). Outbreak of Escherichia coli O157:H7 associated with raw milk consumption in the Pacific Northwest. Foodborne Pathogens and Disease, 5(3), 321-328. http:// dx.doi.org/10.1089/fpd.2007.0072. PMid:18564912.

Dynal. (2000). Dynal bioscience product catalog (pp. 76). Oslo: Dynal.

Fedio, W. M., Jinneman, K. C., Yoshitomi, K. J., Zapata, R., Wendakoon, C. N., Browning, P., \& Weagant, S. D. (2011). Detection of E. coli O157:H7 in raw ground beef by Pathatrix ${ }^{\text {Tw }}$ immunomagneticseparation, real-time PCR and cultural methods. International Journal of Food Microbiology, 148(2), 87-92. http://dx.doi.org/10.1016/j. ijfoodmicro.2011.05.005. PMid:21641670.

Fu, Z., Rogelj, S., \& Kieft, T. L. (2005). Rapid detection of Escherichia coli O157:H7 by immunomagnetic separation and real-time PCR. International Journal of Food Microbiology, 99(1), 47-57. http:// dx.doi.org/10.1016/j.ijfoodmicro.2004.07.013. PMid:15718028.

Ganesh, I., Tran, B. M., Kim, Y., Kim, J., Cheng, H., Lee, N. Y., \& Park, S. (2016). An integrated microfluidic PCR system with immunomagnetic nanoparticles for the detection of bacterial pathogens. Biomedical Microdevices, 18(6), 116. http://dx.doi.org/10.1007/s10544-0160139-y. PMid:27975186.

Gaulin, C., Levac, E., Ramsay, D., Dion, R., Ismail, J., Gingras, S., \& Lacroix, C. (2012). Escherichia coli O157:H7 outbreak linked to raw milk cheese in Quebec, Canada: use of exact probability calculation and casecase study approaches to foodborne outbreak investigation. Journal of Food Protection, 75(5), 812-818. http:// dx.doi.org/10.4315/0362-028X.JFP-11-385. PMid:22564928.

Goh, S., Newman, C., Knowles, M., Bolton, F. J., Hollyoak, V., Richards, S., Daley, P., Counter, D., Smith, H. R., \& Keppie, N. (2002). E. coli 
O157 phage type 21/28 outbreak in North Cumbria associated with pasteurized milk. Epidemiology and Infection, 129(3), 451-457. http://dx.doi.org/10.1017/S0950268802007835. PMid:12558327.

Honish, L., Predy, G., Hislop, N., Chui, L., Kowalewska-Grochowska, K., Trottier, L., Kreplin, C., \& Zazulak, I. (2005). An outbreak of E. coli $\mathrm{O} 157: \mathrm{H} 7$ hemorrhagic colitis associated with unpasteurized Gouda cheese. Canadian Journal of Public Health, 96(3), 182-184. PMid:15913080.

International Standard Organization - ISO. (2001). BS EN ISO 16654: microbiology offood and animal feeding stuffs-horizontal method for the detection of Escherichia coli O157. Geneva: ISO.

Jaakkonen, A., Salmenlinna, S., Rimhanen-Finne, R., Lundstrom, H., Heinikainen, S., Hakkinen, M., \& Hallanvuo, S. (2017). Severe outbreak of sorbitol-fermenting Escherichia coli O157 via unpasteurized milk and farm visits, Finland 2012. Zoonoses and Public Health, 64(6), 468-475. http://dx.doi.org/10.1111/zph.12327. PMid:28045227.

Jeníková, G., Pazlarová, J., \& Demnerová, K. (2000). Detection of Salmonella in food samples by the combination of immunomagnetic separation and PCR assay. International Microbiology, 3(4), 225-229. PMid:11334305.

King, L. A., Loukiadis, E., Mariani-Kurkdjian, P., Haeghebaert, P., Weill, F. X., Baliere, C., Ganet, S., Gouali, M., Vaillant, V., Pihier, N., Callon, H., Novo, R., Gaillot, O., Thevenot-Sergentet, D., Bingen, E., Chaud, P., \& Valk, H. (2014). Foodborne trans-mission of sorbitol-fermenting Escherichia coli O157:[H7] via ground beef: an outbreak in northern France, 2011. Clinical Microbiology and Infection, 20(12), O1136-O1144. http://dx.doi.org/10.1111/14690691.12736. PMid:24962059.

Kraft, A. L., Lacher, D. W., Shelver, W. L., Sherwood, J. S., \& Bergholz, T. M. (2017). Comparison of immunomagnetic separation beads for detection of six non-O157 Shiga toxin-producing Escherichia coli serogroups in different matrices. Letters in Applied Microbiology, 65(3), 213-219. http://dx.doi.org/10.1111/lam.12771. PMid:28656639.

Kumar, A., Grover, S., \& Kumar Batish, V. (2013). Application of multiplex PCR assay based on uidR and fliCH7 genes for detection of Escherichia coli O157:H7 in milk. The Journal of General and Applied Microbiology, 59(1), 11-19. http://dx.doi.org/10.2323/ jgam.59.011. PMid:23518514.

Lionberg, W. C., Restaino, L., Frampton, E. W., \& Barbour, W. M. (2003). Efficacy of enrichment broths in the recovery of freezeinjured Escherichia coli O157:H7 in inoculated ground beef by PCR. Journal of Food Protection, 66(10), 1911-1915. http://dx.doi. org/10.4315/0362-028X-66.10.1911. PMid:14572231.

Luo, D., Huang, X. L., Mao, Y., Chen, C. C., Li, F. L., Xu, H. Y., \& Xiong, Y. H. (2017). Two-step large-volume magnetic separation combined with PCR assay for sensitive detection of Listeria monocytogenes in pasteurized milk. Journal of Dairy Science, 100(10), 7883-7890. http://dx.doi.org/10.3168/jds.2017-13140. PMid:28803008.

McCollum, J. T., Williams, N. J., Beam, S. W., Cosgrove, S., Ettestad, P. J., Ghosh, T. S., Kimura, A. C., Nguyen, L., Stroika, S. G., Vogt, R. L., Watkins, A. K., Weiss, J. R., Williams, I. T., \& Cronquist, A. B. (2012). Multistate outbreak of Escherichia coli O157:H7 infections associated with in-store sampling of an aged raw-milk Gouda cheese. Journal of Food Protection, 75(10), 1759-1765. http://dx.doi. org/10.4315/0362-028X.JFP-12-136. PMid:23043823.

Mendonca, M., Conrad, N. L., Conceição, F. R., Moreira, A. N., Silva, W. P., Aleixo, J. A. G., \& Bhunia, A. K. (2012). Highly specific fiber optic immunosensor coupled with immunomagnetic separation for detection of low levels of Listeria monocytogenes and L. ivanovii. BMC Microbiology, 12, 275. PMid:23176167.
Mercanoglu Taban, B., \& Aytac, S. A. (2009). Application of magnetic immuno-polymerase chain reaction assay for detection of Salmonella spp. in chicken meats. European Food Research and Technology, 229(4), 623-628. http://dx.doi.org/10.1007/s00217-009-1091-3.

Mercanoglu, B., \& Aytac, S. A. (2006). Prevalence of Escherichia coli O157:H7 in various foods in Turkey: a study on the use of the IMS technique. Archiv fur Lebensmittelhygiene, 57(3), 76-79.

Mercanoglu, B., \& Griffiths, M. W. (2005). Combination of immunomagnetic separation with real-time PCR for rapid detection of Salmonella in milk, ground beef, and alfalfa sprouts. Journal of Food Protection, 68(3), 557-561. http://dx.doi.org/10.4315/0362-028X-68.3.557. PMid:15771182.

Morgan, D., Newman, C. P., Hutchinson, D. N., Walker, A. M., Rowe, B., \& Majid, F. (1993). Verotoxinproducing Escherichia coli O157 infections associated with the consumption of yoghurt. Epidemiology and Infection, 111(2), 181-187. http://dx.doi.org/10.1017/ S0950268800056880. PMid:8405146.

Nordstrom, J. L., Vickery, M. C. L., Blackstone, G. M., Murray, S. L., \& Depaola, A. (2007). Development of a multiplex real-time PCR assay with an internal amplification control for the detection of total and pathogenic Vibrio parahaemolyticus bacteria in oysters. Applied and Environmental Microbiology, 73(18), 5840-5847. http://dx.doi. org/10.1128/AEM.00460-07. PMid:17644647.

Qin, Y., Puthiyakunnon, S., Zhang, Y., Wu, X., Boddu, S., Luo, B., \& Fan, H. (2018). Rapid and specific detection of Escherichia coli O157:H7 in ground beef using immunomagnetic separation combined with loop-mediated isothermal amplification. Polish Journal of Food and Nutrition Sciences, 68(2), 115-123. http://dx.doi.org/10.1515/ pjfns-2017-0014.

Roche/BIOTECON Diagnostics. (2007). Roche/BIOTECON Diagnostics Foodproof ${ }^{B}$ ShortPrep I product manual (pp. 8). Germany: Roche/ BIOTECON Diagnostics.

Roche/BIOTECON Diagnostics. (2017). Roche/BIOTECON Diagnostics Foodproof ${ }^{\circledR}$ E. coli O157 Detection Kit product manual (pp. 20). Germany: Roche/BIOTECON Diagnostics.

Rodriguez-Lázaro, D., Pla, M., Scortti, M., Monzo, H. J., \& Vazquez-Boland, J. A. (2005). A novel real-time PCR for Listeria monocytogenes that monitors analytical performance via an internal amplification control. Applied and Environmental Microbiology, 71(12), 9008-9012. http:// dx.doi.org/10.1128/AEM.71.12.9008-9012.2005. PMid:16332910.

Schrader, C., Schielke, A., Ellerbroek, L., \& Johne, R. (2012). PCR inhibitors-occurrence, properties and removal. Journal of Applied Microbiology, 113(5), 1014-1026. http://dx.doi.org/10.1111/j.13652672.2012.05384.x. PMid:22747964.

Wang, H., Li, Y., Wang, A., \& Slavik, A. (2011). Rapid, sensitive, and simultaneous detection of three foodborne pathogens using magnetic nanobeadbased immunoseparation and quantum dotbased multiplex immunoassay. Journal of Food Protection, 74(12), 2039-2047. http:// dx.doi.org/10.4315/0362-028X.JFP-11-144. PMid:22186043.

Wang, L., Li, P., Yang, Y., Xu, H., Aguilar, Z., Xu, H., Yang, L., Xu, F., Lai, W., Xiong, D., \& Wei, H. (2014). Development of an immunomagnetic separation-propidium monoazide-polymerase chain reaction assay with internal amplification control for rapid and sensitive detection of viable Escherichia coli O157:H7 in milk. International Dairy Journal, 34(2), 280-286. http://dx.doi.org/10.1016/j.idairyj.2013.07.006.

Weagant, S. D., \& Bound, A. J. (2001). Evaluation of techniques for enrichment and isolation of Escherichia coli O157:H7 from artificiallycontaminated sprouts. International Journal of Food Microbiology, 71(1), 87-92. http://dx.doi.org/10.1016/S0168-1605(01)00558-X. PMid:11764896. 
Weagant, S. D., Jinneman, K. C., Yoshitomi, K. J., Zapata, R., \& Fedio, W. M. (2011). Optimization and evaluation of a modified enrichment procedure combined with immunomagnetic separation for detection of E. coli O157:H7 from artificially contaminated alfalfa sprouts. International Journal of Food Microbiology, 149(3), 209-217. http://dx.doi.org/10.1016/j.ijfoodmicro.2011.06.008. PMid:21784545.

Xiong, Q., Cui, X., Saini, J. K., Liu, D., Shan, S., Jin, Y., \& Lai, W. (2014). Development of an immunomagnetic separation method for efficient enrichment of Escherichia coli O157:H7. Food Control, 37, 41-45. http://dx.doi.org/10.1016/j.foodcont.2013.08.033.
Yang, H., Qu, L., Wimbrow, A. N., Jiang, X., \& Sun, Y. (2007). Rapid detection of Listeria monocytogenes by nanoparticle-based immunomagnetic separation and real-time PCR. International Journal of Food Microbiology, 118(2), 132-138. http://dx.doi.org/10.1016/j. ijfoodmicro.2007.06.019. PMid:17716768.

Zhao, X., Li, Y., Wang, L., You, L., Xu, Z., Li, L., He, X., Liu, Y., Wang, J., \& Yang, L. (2010). Development and application of a loop-mediated isothermal amplification method on rapid detection Escherichia coli O157 strains from food samples. Molecular Biology Reports, 37(5), 2183-2188. http://dx.doi.org/10.1007/s11033-009-9700-6. PMid:19685165. 